\title{
Influence of Board Density and Wood/Cement Ratio on the Properties of Wood-Cement Composite Panels Made from Date Palm Fronds and Tree Prunings of Buttonwood
}

\author{
Ramadan A. Nasser ${ }^{1}$
}

\begin{abstract}
As part of a large project funded by National Plane for Science and Technology (NPST), the midribs of date palm trees (Phoenix dactylifera L.) and tree prunings of buttonwood (Conocarpus erectus L.) were used to manufacture wood-cement panels (WCPs) of high-quality from lignocellulosic materials available in Saudi Arabia. This work aimed to evaluate the effects of board density and wood/cement ratio (WCR) on the properties of the produced WCPs. Such WCPs were produced under specific manufacturing variables, including targeted board density $\left(1100,1200\right.$ and $\left.1300 \mathrm{~kg} . \mathrm{m}^{-3}\right)$ and WCR $(1 / 2,1 / 3$ and $1 / 4$ by weight). The mechanical properties and dimensional stability of the final panels were determined. The results indicated that the WCPs could be made from the two species after pre-treating the particles with an aqueous treatment and adding either calcium or magnesium chloride as an accelerator. Both the board density and WCP had significant effects on the properties of the WCPs from each species. The mechanical and dimensional properties of the WCPs increased as the board density increased from 1100 to $1300 \mathrm{~kg} \cdot \mathrm{m}^{-3}$. It has been found that all the mechanical properties of the WCPs were directly related to the board density. The results revealed that as the WCR increased from $1 / 2$ to $1 / 4$, the dimensional stabilities and mechanical properties of the WCPs, except for the modulus of rupture, increased. The properties of the produced panels were improved by increasing the WCR. For WCP industry production, the choice of proper wood species, board density and WCR should be made based on the end uses of the panels.
\end{abstract}

Keywords

Board density, date palm midrib, dimensional stability, mechanical properties, tree prunings, wood-cement panels, $\mathrm{wood} /$ cement ratio.

\section{INTRODUCTION}

Agricultural residues are renewable resources that can be utilized as raw materials in the wood industry ${ }^{1}$. A wide variety of agricultural residues and non-woody materials, such as midribs of date palm and wheat straw $^{2}$, rattan $^{3}$, arhar stalks ${ }^{4}$, bamboo $^{5}$, and coconut shell of babacu ${ }^{1}$ have been studied. Fortunately, Saudi Arabia has relatively large quantities of lignocellulosic materials, including tree prunings and date palm residues, available in the form of agricultural residues.

Buttonwood (Conocarpus erectus L.) is known as a salt-tolerant forest species with a moist native habitat. Recently, it has been increasingly used as an ornamental tree in Saudi Arabia. The large buttonwood population in Saudi Arabia sheds a substantial quantity of residues annually as the result of seasonal pruning, which is an essential agricultural practice. No data are available in this field concerning the average quantity of residue from Buttonwood tree prunings ${ }^{6}$. However, in the Kingdom of Saudi Arabia, the number of date palm trees exceeds 28 million $^{7}$; assuming an average of $35 \mathrm{~kg}$ of palm residues are obtained per tree annually, about 1 million metric tons of date palm biomass are wasted annually from the seasonal trimming of the palm tree population in Saudi Arabia. In developed countries, these residues are used to produce valuable wood-based panels, such as particleboard and medium density fiberboard (MDF), although in most of the developing world, they are simply burnt to ashes ${ }^{2}$.

Inorganic-bonded composites are referred to as particles or fibers of wood or non-wood materials and are used as reinforcement materials, bonded and held together by an inorganic binder such as ordinary Portland cement. These composites can be molded or compressed blocks and panels, containing approximately $30-70 \%$ by weight of wood in various forms ${ }^{8}$. These panels have excellent sound insulation, highly resistant to water, termites, and excellent for outdoor use, which has led to their wide potential applications for replacing traditional building materials and conventional wood composites as roofing, wall, flooring parts, and noise insulation?

The properties of WCPs are affected by many processing factors. The types of raw material used, the wood particle size, the board density and the wood to cement ratio are the most important factors affecting the properties of WCPs. Previous studies have revealed that not all species react favorably with cement ${ }^{4,10}$. Many researchers have reported that the wood particle size has

\footnotetext{
${ }^{1}$ Plant Production Department, College of Food and Agriculture Sciences, King Saud University, Riyadh, Saudi Arabia, and Forestry and Wood Technology Department, Faculty of Agriculture, Alexandria University, Alexandria, Egypt. Corresponding author: E-mail: nasser67@ksu.edu.sa Received May 6, 2014, Accepted June 28,2014
} 
a large effect on the properties of $\mathrm{WCPs}^{11}$. The effects of the board density and WCR as manufacturing factors have been studied in different parts of the world for many types of woody materials ${ }^{10,12-15}$ and shown to significantly affect the properties of the produced WCPs. In Saudi Arabia, several studies have been undertaken to test the suitability of some wood species and agricultural residues that are available in Saudi Arabia for WCP manufacturing ${ }^{2,16-17}$. Without producing actual WCPs, these studies determined the suitability of the woody materials using hydration tests as well as pretreatments and chemical additives to enhance the compatibility of the materials with cement. They concluded that with some pretreatment and specific chemical additives, most of the woody materials available in Saudi Arabia are suitable for WCP manufacturing. However, the properties of WCPs manufactured from these woody materials have not been determined.

Accordingly, the current work aimed to evaluate the properties of WCP's made from the date palm residues and tree prunings of buttonwood as well as to study the effects of board target density and WCR on the properties of the corresponding WCPs.

\section{MATERIALS AND METHODS}

\section{Raw materials}

Tree prunings of buttonwood (Conocarpus erectus L.) and date palm midribs (Phoenix dactylifera L.) growing in Riyadh city were collected during 2011 to be used as lignocellulosic raw materials for manufacturing wood-cement panels (WCPs). After collecting and air-drying, the woody materials were cut into small pieces or discs using a band saw and fed through a laboratory hammer mill using a $5 \mathrm{~mm}$ screen. Two particle sizes were used in the current study: 1) particles passed through a $0.8-\mathrm{mm}$ sieve and retained on a $0.4-\mathrm{mm}$ sieve $(-20 /+40$ mesh $)$ were used for manufacturing the WCPs, and 2) particles passed through a $0.4-\mathrm{mm}$ sieve and retained on a $0.27-\mathrm{mm}$ sieve $(-40 /+60 \mathrm{mesh})$ were used for the chemical analysis of wood. The wood particles $(-20 /+40$ mesh) were pretreated by either cold water soaking or hot water extraction before used for WCP manufacturing according to Nasser ${ }^{18}$ and Moslemi et al. ${ }^{19}$. Commercial Portland cement (Type I), meeting ASTM specifications (ASTM C150) ${ }^{20}$ and manufactured by the Yamama Saudi Cement Company Limited, was used in this study as a binder. The chemical composition, as provided by the supplier, is shown in Table 1.

\section{Chemical analysis of woody materials}

Based on the oven-dried weight, the percent of total extractives of the wood samples $(-40 /+60$ mesh) were determined according to ASTM D $1037^{21}$. The amount of cellulose, hemicellulose, and lignin contents were determined using free-extractives meal according to the standard method. In addition, the ash content and cold water solubility of wood were also determined according to NREL ${ }^{22}$.

\section{Hydration test}

To evaluate the compatibility of the two woody materials with cement and to select the best treatment for WCP manufacturing, a preliminary hydration experiment was conducted according to Hachmi et al. ${ }^{23}$ using a 2-L Dewar flask. Every possible combination of pre-treatment procedure (untreated, cold water and hot water) and chemical addition (none, $\mathrm{CaCl}_{2}, \mathrm{Al}_{2}\left(\mathrm{SO}_{4}\right)_{3}$ or $\mathrm{MgCl}_{2}$ ) was tested (twelve treatments in total). Exothermic hydration curves were obtained and hydration data were recorded, then the indices of hydration were calculated, including the inhibitory index ${ }^{19}$ and compatibility factor ${ }^{23}$.

\section{Water requirements for WCPs manufacturing}

The quantity of water used to manufacture the WCPs was determined using the formula developed by Simatupang et $a .^{24}$, with some modifications. The optimum amount of water per each gram of cement needed to complete hydration was determined by the hydration test and calculated using the uniform mixing index ${ }^{23}$. The optimal water/cement ratio and water/wood ratio were determined to be 0.28 and $0.55 \mathrm{~mL} \cdot \mathrm{g}^{-1}$, respectively.

Table 1. Properties of ordinary Portland cement (Type I).

\begin{tabular}{lccccccccc}
\hline & \multicolumn{4}{c}{ Chemical composition (\%) } & \multicolumn{3}{c}{ Setting time (min) } & $\mathbf{C}_{\max }$ \\
\cline { 2 - 11 } & $\mathbf{S i O}_{\mathbf{2}}$ & $\mathbf{A l}_{\mathbf{2}} \mathbf{O}_{\mathbf{3}}$ & $\mathbf{F e}_{\mathbf{2}} \mathbf{O}_{\mathbf{3}}$ & $\mathbf{C a O}$ & $\mathbf{M g O}$ & $\mathbf{S O}_{\mathbf{3}}$ & Initial & Final & (MPa) \\
\hline Cement used & 20.46 & 5.69 & 3.88 & 64.82 & 0.72 & 2.55 & 105 & 165 & 29.9 \\
\hline ASTM $^{*}$ & $(-)$ & $(-)$ & $(-)$ & $(-)$ & Max 6.0 & Max 3.5 & Min. 45 & Max. 375 & Min. 19.7 \\
\hline
\end{tabular}

Reported by supplier (Yamama Saudi Cement Company Limited).

(-) limit is not specified.

The time of setting was determined by the Vicat test method.

$\mathrm{C}_{\max }$ is the compressive strength of the cement after 7 days.

According to the standard specification for Portland cement ${ }^{20}$. 


\section{WCP preparation}

According to the results of the hydration tests observed in Table 2, WCPs were manufactured using the best treatments, including a pre-treatment (cold or hot water) and the addition of chemical additives $\left(\mathrm{CaCl}_{2}\right.$ or $\mathrm{MgCl}_{2}$ ), according to a method outlined by Okino et al. ${ }^{25}$ and Papadopoulos ${ }^{26}$. To achieve both board density of WCP and WCR, variable amount of ovendried wood particles and chemical aqueous solution (chemical additives dissolved in distilled water) were hand mixed. Then, Portland cement (Type I) was added to the wet particles, and the constituents were thoroughly mixed until the cement paste was completely hydrated. The quantity of distilled water was calculated according to the relationship developed by Simatupang $^{24}$. After approximately $15 \mathrm{~min}$ of hand mixing, an open-top box of composite wood coated with a phenolic layer with dimensions of $30 \times 30 \mathrm{~cm}$ for the base on the inside and of $3.1 \mathrm{~cm}$ for the height was designated to form the panel. The mat was then coldpressed using a hydraulic press (Carver Monarch) to a $10 \mathrm{~mm}$ thickness, and the panel was kept under a constant pressure for $20 \mathrm{~h}$ using the press clamp. The panels were carefully extracted from the mold, misted with water, wrapped in cellophane and aligned before conditioning at room temperature and relative humidity for a minimum of 1 month. In total, 54 panels were manufactured, representing two wood species, three targeted densities, WCRs and three panels per combination. The specifications of the WCPs are presented in Table 3.

\section{Mechanical properties of WCPs}

Using an Instron Testing Machine (Model 3382) in accordance with ASTM D-1037 $7^{21}$ with some modifications due to the limited size of the panels, tests of the static bending, the tensile strength perpendicular to the board surface (IB), the screw withdrawal and the Janka hardness were carried out on the WCPs. The modulus of rupture (MOR), modulus of elasticity (MOE), internal bond strength (IBS), screw holding power (SHP) and Janka hardness number (JHN) were recorded. The densities and moisture contents of the WCPs in the static bending test were determined by cutting the samples near the failure zone. The specimen dimensions, head speed and calculated parameters are shown in Table 4.

\section{Dimensional stability properties}

The water uptake (WU), thickness swelling (TS) and linear expansion (LE) of the WCPs were determined after changing from equilibrium conditions to water immersion for $24 \mathrm{~h}$ (ASTM D-1037) ${ }^{21}$. The specimens were immersed in a water bath at room temperature for $24 \mathrm{~h}$, then taken out and weighed. All calculation were expressed as a percentage of the original state after 24 h.

Table 2. Hydration parameters for the best treatments selected for the WCP manufacture.

\begin{tabular}{lccccccc}
\hline \multirow{2}{*}{ Wood Species } & \multicolumn{2}{c}{ Best treatment } & \multicolumn{4}{c}{ Hydration data and indices } \\
& $\begin{array}{c}\text { Pre- } \\
\text { treatment }\end{array}$ & $\begin{array}{c}\text { Chemical } \\
\text { additive }\end{array}$ & $\mathbf{T}_{\max }$ & $\Delta \mathbf{T}$ & $\mathbf{t}_{\mathbf{m a x}}$ & $\mathbf{I}$ & $\mathbf{C}_{\mathbf{A}}$ \\
& $\left.\mathbf{(}^{\mathbf{0}} \mathbf{C}\right)$ & $\mathbf{( { } ^ { \mathbf { 0 } } \mathbf { C } )}$ & $\mathbf{( h r s )}$ & $\mathbf{( \% )}$ \\
\hline Phoenix dactylifera & Untreated & Without & 38.40 & 16.70 & 24.0 & 148.6 & 39.58 \\
& $\mathrm{HWE}$ & $\mathrm{MgCl}_{2}$ & 73.10 & 48.70 & 3.50 & -2.42 & 85.71 \\
& Untreated & Without & 51.10 & 28.60 & 8.50 & 12.46 & 58.25 \\
& $\mathrm{CWS}$ & $\mathrm{CaCl}_{2}$ & 75.53 & 52.60 & 3.17 & -0.76 & 86.07 \\
\hline Net cement & - & - & $\mathbf{8 8 . 6 0}$ & $\mathbf{6 5 . 6}$ & $\mathbf{6 . 2 5}$ & $\mathbf{0}$ & $\mathbf{1 0 0}$ \\
\hline
\end{tabular}

CWS: cold water soaking, HWE: hot water extraction.

$\mathrm{T}_{\max }$ : maximum temperature, $\Delta \mathrm{T}$ : rise in temperature above room temperature,

$\mathrm{t}_{\max }$ : time to reach $\mathrm{T}_{\max }$, I: inhibitory index and $\mathrm{C}_{\mathrm{A}}$ : compatibility factor.

Table 3. Specifications of the WCPs.

\begin{tabular}{lcl}
\hline Condition & Unit & \multicolumn{1}{c}{ Value } \\
\hline Wood/cement ratio by weight & $\mathrm{g} / \mathrm{g}$ & $1 / 2,1 / 3 \& 1 / 4$ \\
Board density & $\mathrm{Kg} \cdot \mathrm{m}^{-3}$ & 1100,1200 and 1300 \\
Wood particle size* & $\mathrm{mesh}$ & $-20 /+40$ \\
Total pressure & $\mathrm{MPa}$ & 3.5 to 4.5 and clamped for $20 \mathrm{~h}$. \\
Press time & $\mathrm{h}$ & $4 \mathrm{~h}$ under hydraulic press and $20 \mathrm{~h}$ under clamp press \\
Conditioning & ${ }^{\circ} \mathrm{C}$ & Room temperature $\left(20 \pm 2^{\circ} \mathrm{C}\right)$ \\
& $\%$ & Relative humidity $(65 \pm 2 \%)$ \\
\hline Panel dimensions & $\mathrm{mm}$ & $300 \times 300 \times 10$ \\
\hline
\end{tabular}


* (-) means pass and (+) means retained on a sieve screen.

Table 4. Test specimen dimensions of WCPs, loading rate and calculated parameters

\begin{tabular}{lccclc}
\hline Test & \multicolumn{2}{c}{$\begin{array}{c}\text { Dimension }(\mathbf{m m}) \\
\text { Width }\end{array}$} & $\begin{array}{c}\text { length } \\
\text { Head speed* } \\
(\mathbf{m m} \backslash \mathbf{m i n})\end{array}$ & \multicolumn{1}{c}{$\begin{array}{c}\text { Calculated } \\
\text { parameter }\end{array}$} & Unit \\
\hline Static bending & 50 & 250 & 6.6 & MOR (modulus of rupture) & $\mathrm{MPa}$ \\
& 50 & 250 & 6.6 & MOE (modulus of elasticity) & $\mathrm{GPa}$ \\
& - & - & - & Density & $\mathrm{g.cm}^{-3}$ \\
& - & - & - & Moisture content & $\%$ \\
Tensile $\perp$ panel surface & 50 & 50 & 2.0 & IB (internal bond) & $\mathrm{MPa}$ \\
Screw withdrawal & 75 & 75 & 2.0 & SHP (screw holding power) & $\mathrm{N}$ \\
\hline Janka hardness & 75 & 75 & 0.61 & JHN (Janka hardness number) & $\mathrm{N}$ \\
\hline
\end{tabular}

* The head speed is the rate of load applied.

The span for static bending is $230 \mathrm{~mm}$.

The thickness of the specimens is equal to the thickness of the WCP $(10 \mathrm{~mm})$, except for in the Janka hardness test, in which the thickness was made $20 \mathrm{~mm}$ by gluing together two specimens.

\section{Statistical analysis}

To investigate the significant differences in physical, mechanical and dimensional stability properties of the

WCPs, randomized complete design (CRD) in two factors was used. The $\mathrm{T}$ data were analyzed by analysis of variance (ANOVA), and the mean values were tested by the LSD test $(p<0.05)$ to study the significance of the differences between species and among the target densities of the panels using the $\mathrm{SAS}^{27}$ statistical package.

\section{RESULTS AND DISCUSSION}

\section{Selection of the treatment for WCP manufacturing}

The exothermic hydration curves and the hydration data for the two species used in the current study to produce WCPs are presented in Figs. $1 \& 2$ and in Table 2. The exothermic curves revealed that both species could not be used directly as raw materials for WCP production and that they must first be pre-treated by either cold or hot water with the addition of $\mathrm{CaCl}_{2}$ or $\mathrm{MgCl}_{2}$ (3\% by weight). It can be observed that the best treatment differed depending on the species (Figs. 1 \& 2 ). Using the best treatment, the materials were suitable for WCP production according to Hachmi et al. ${ }^{23}$. The results showed that the time to reach the maximum temperature $\left(\mathrm{t}_{\max }\right)$ ranged from 3.2 to $3.5 \mathrm{~h}$, so the panels were pressed in an automatic hydraulic press for at least $4 \mathrm{~h}$ and then clamped for $20 \mathrm{~h}$ before removal from the mold. These results are in agreement with previously published reports ${ }^{3}$. The negative values of the inhibitory indexes (I) may be attributed to the minimization of the adverse effects of the soluble sugars and extractives as well as to the acceleration of the cement hardening and setting ${ }^{28}$.

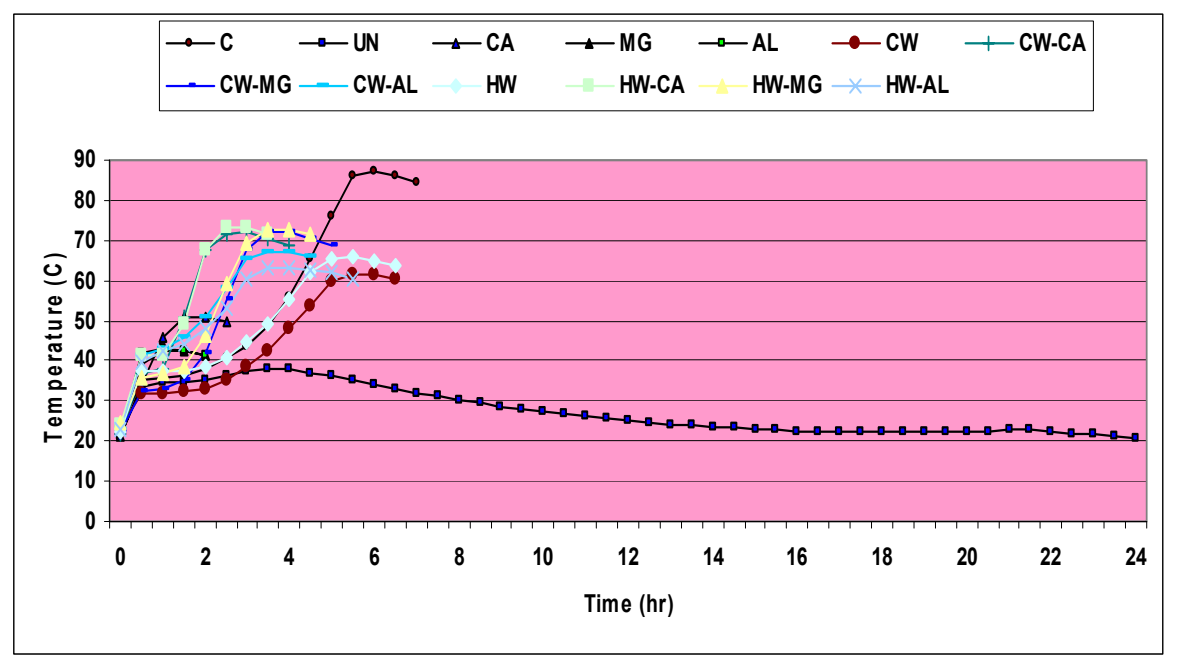

Fig. 1. Exothermic hydration curves of $P$. dactylifera midrib-cement mixtures under different treatments

C: cement, UN: Untraeated, $\mathrm{CA}: \mathrm{CaCl}_{2}, \mathrm{MG}: \mathrm{MgCl}_{2}, \mathrm{AL}$ : $\mathrm{Al}\left(\mathrm{So}_{4}\right)_{2}, \mathrm{CW}$ : cold water soaking, $\mathrm{HW}$ : hot water extraction 


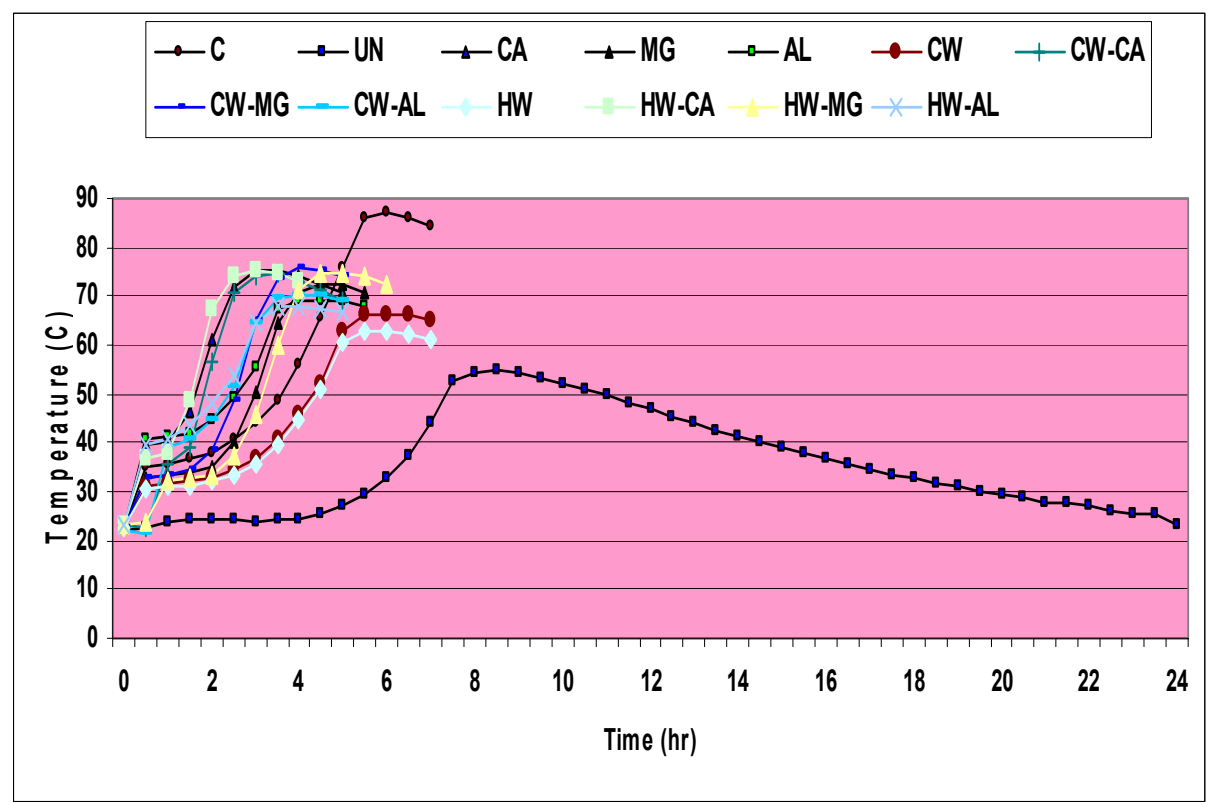

\section{Fig. 2. Exothermic hydration curves of $C$. erectus wood-cement mixtures under different} treatments. For legend see Fig.1.

\section{Chemical analysis of the two species}

The most important factor affecting the compatibility between wood and cement as well as the mechanical properties of the produced WCPs was the chemical composition of the wood. A comparison of the chemical composition of the midribs of $P$. dactylifera and the tree prunings of $C$. erectus to hardwood is presented in Table 5. It can be observed that there are significant differences in all chemical constituents between the two species. These variations might be explain the differences among the produced WCPs. It was evident that, except for the cold water solubility of the midribs of $P$. dactylifera as well as the extractives content and ash content of the two species, all chemical constituents fell within the range of those of hardwood species. The last two parameters are the most important factors influencing the compatibility between wood and cement ${ }^{19}$. Pre-treatment of the wood particles most likely removed many of the extraneous substances that inhibit the setting of cement, resulting in stronger bonding between the wood particles and the cement and improved mechanical properties in the produced WCPs $^{11,17-19}$. The ash contents of the two species were very high when compared with those of hardwood species (Table 5). Generally, it is known that the ash content of wood is less than $1 \%$; however, many researchers have been reported that most wood species grown in Saudi Arabia have a higher ash contents of above $2 \%{ }^{17}$.

\section{Effect of the species on the properties of the WCPs}

The mean values of and significant differences in the mechanical and dimensional stability properties of the WCPs made from the date palm midribs and the tree prunings of buttonwood are presented in Table 6 and Fig. 3. Some of these properties significantly differed according to species, i.e., had a significant effect on the properties of the produced WCPs. It can be observed that the differences in the modulus of elasticity (MOE), screw holding power (SHP), and Janka hardness number $(\mathrm{JHN})$ between the two species were statistically significant. The WCPs from $C$. erectus showed the highest values for mechanical properties and the lowest values for water uptake (WU), thickness swelling (TS) and linear expansion (LE) after soaking in water for $24 \mathrm{~h}$. The inverse was true for the WCPs from the date palm midribs. The WCPs from $C$. erectus maintained higher stability in water than those produced from $P$. dactylifera. Generally, the mechanical properties of the WCPs made from the two species surpassed the minimum requirements; the dimensional stability characteristics of the panels were also lower than the maximum limits of particleboard standards. These results agree with those reported by other researchers around the world ${ }^{26}$. WCPs could be made from the midribs of date palm ( $P$. dactylifera) and the tree prunings of buttonwood $(C$. erectus) after pretreating the particles by aqueous treatment and adding either calcium or magnesium chloride as an accelerator.

Although the screw holding power and Janka hardness strength $(\mathrm{JHN})$ of a produced panel are the 
most important measurements for construction and flooring applications, no requirements are specified in the ISO standard for CBP panels. The values of the SHP are comparable with those reported by Okino et $a l^{25}$ for WCPs made from a mixture of eucalypt and rubberwood (1500 to $2020 \mathrm{~N}$ ); however, they are higher than those from Almeida et al. ${ }^{1}$ for WCPs produced from the coconut shell of babaçu (474 to $1146 \mathrm{~N})$. A higher JHN value was observed for C. erectus $(5371 \mathrm{~N})$ and a lower value was recorded for $P$. dactylifera $(5795$ $\mathrm{N})$.No values were available in the literature for comparison.

Table 5. Chemical analysis of the two species used for the manufacture of WCPs.

\begin{tabular}{lccccc} 
& & \multicolumn{2}{c}{ Percentage content of } & & \\
Wood species & Extractives* & Holocellulose & Lignin & Ash & CWS \\
\hline Phoenix dactylifera & $20.31^{\mathrm{A}} \pm 2.3$ & $75.0^{\mathrm{A}} \pm 4.6$ & $25.8^{\mathrm{B}} \pm 3.5$ & $1.33^{\mathrm{B}} \pm 0.7$ & $14.65^{\mathrm{A}} \pm 1.9$ \\
Conocarpus erectus $^{\mathrm{A}}$ & $10.86^{\mathrm{B}} \pm 1.4$ & $65.0^{\mathrm{B}} \pm 5.3$ & $35.2^{\mathrm{A}} \pm 4.8$ & $2.21^{\mathrm{A}} \pm 1.0$ & $4.83^{\mathrm{B}} \pm 1.6$ \\
\hline Hardwood $^{+}$ & $\mathbf{2 - 8}$ & $\mathbf{6 0 - 8 5}$ & $\mathbf{2 3 - 3 0}$ & $\mathbf{0 . 2 - 0 . 5}$ & $\mathbf{4 - 6}$ \\
\hline
\end{tabular}

Each value is an average of 5 samples.

* Total extractives by ASTM D1105 (1989) ${ }^{21}$.

CWS is cold water solubility.

Means with the same letter in a column are not significantly different at a 0.05 level of probability according to the LSD test.

+ Fengel and Wegener ${ }^{29}$.

Table 6. Mean values* of the properties of the WCPs from the buttonwood and date palm midribs.

\begin{tabular}{lcccccccc}
\hline & \multicolumn{4}{c}{ Mechanical properties } & \multicolumn{3}{c}{ Dimensional stability (\%) } \\
& MC & Density $^{+}$ & MOR & IB & JHN & Water & Thickness & Linear \\
\hline Wood species & $\mathbf{( \% )}$ & $\left.\mathbf{( k g . m}^{-3}\right)$ & $\mathbf{~ M P a )}$ & $\mathbf{( M P a )}$ & $\mathbf{( N )}$ & uptake & swelling & expansion \\
\hline$P$. dactylifera & $8.45^{\mathrm{A}}$ & $1250^{\mathrm{A}}$ & $11.20^{\mathrm{A}}$ & $1.76^{\mathrm{A}}$ & $5795^{\mathrm{A}}$ & $23.03^{\mathrm{A}}$ & $1 . .34^{\mathrm{A}}$ & $0.50^{\mathrm{A}}$ \\
C. erectus & $8.65^{\mathrm{A}}$ & $1255^{\mathrm{A}}$ & $11.75^{\mathrm{A}}$ & $1.74^{\mathrm{A}}$ & $5371^{\mathrm{B}}$ & $19.34^{\mathrm{B}}$ & $0.57^{\mathrm{B}}$ & $0.34^{\mathrm{B}}$ \\
\hline Requirement & - & 1200 & 9.00 & 0.45 & 2222 & - & Max 8.0 $^{-}$ & - \\
\hline
\end{tabular}

* Each value is an average of 27 specimens.

+ Board density based on oven-dry weight and volume at test ${ }^{21}$.

Means with the same letter in a column are not significantly different at a 0.05 level of probability according to the LSD test. MC: moisture content, MOR: modulus of rupture, IB: internal bond, JHN: Janka hardness number.

The dimensional stability was determined after $24 \mathrm{~h}$ of water soaking.

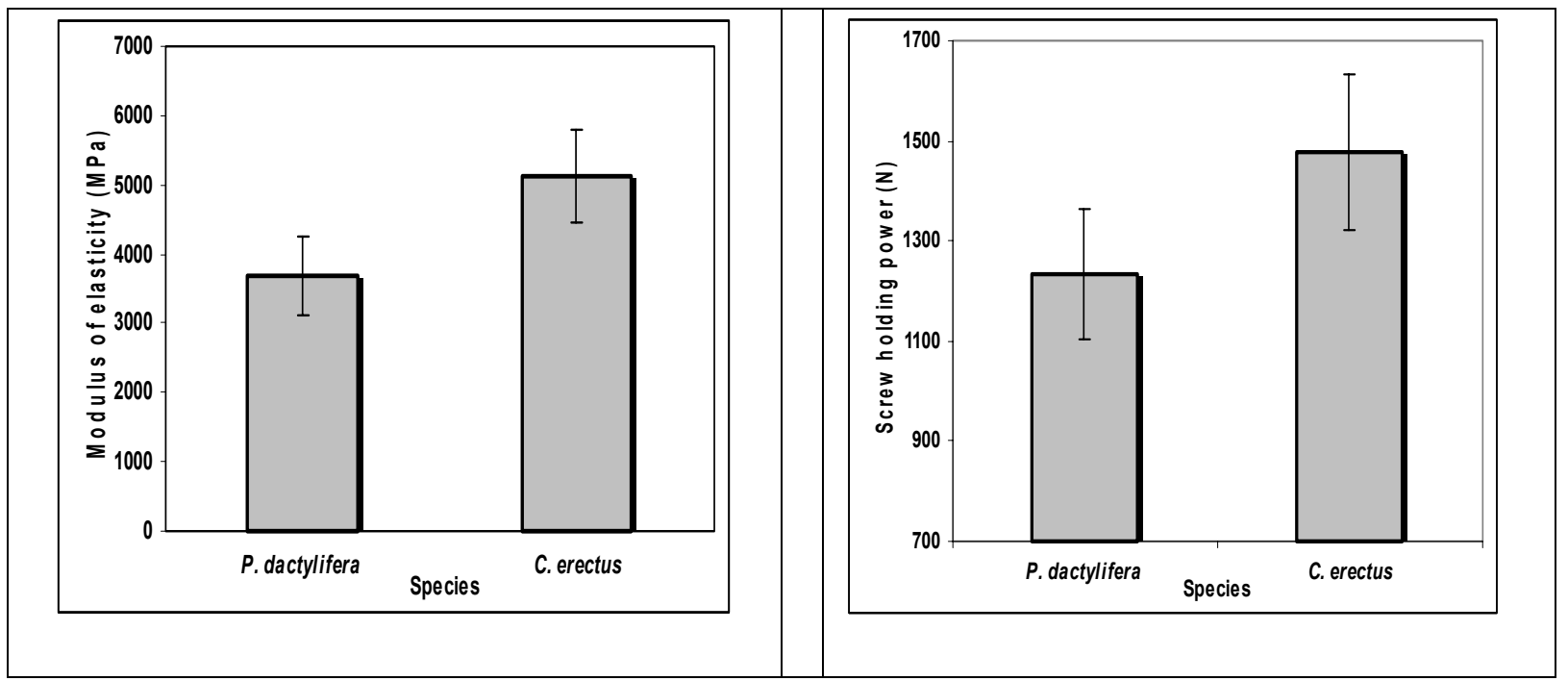

Fig. 3. Modulus of elasticity and screw holding power of the WCPs from the date palm midribs and Buttonwood prunings 


\section{Effects of species and board density on the properties of WCPs}

In the composite industries, i.e., particleboard manufacture, choosing the proper particleboard density is a very important step, and the proper density can be determined based on the intended application requirements. For example, particleboards with low density are often used as soundproofing materials ${ }^{30}$. The board targeted density is planned before manufacturing the panels based on the relationship between board density, oven-dry weight and the volume of the boards (dimensions and thickness). By choosing the targeted board density necessary to produce, e.g., $1200 \mathrm{~kg} . \mathrm{m}^{-3}$, we can calculate the weight of each component including wood and cement necessary to give the desired board density.

The analysis of variance indicated that the interactions between species and the board target density (BTD), except MC, were highly significant for all the mechanical properties (MOR, MOE, IB, SHP, and $\mathrm{JHN}$ ) and dimensional stability characteristics of the WCPs. Table 7 shows the mean values of the mechanical properties and dimensional stability characteristics of the WCPs manufactured from the two species under three levels of board density.

Generally, it can be observed from these results that for each species, the values of MOR, MOE, IB, SHP, and $\mathrm{JHN}$ increased as the BTD increased from 1100 to $1300 \mathrm{~kg} \cdot \mathrm{m}^{-3}$. The lowest values were obtained for the panels made at low BTD $\left(1100 \mathrm{~kg} \cdot \mathrm{m}^{-3}\right)$, and the highest were obtained for the panels made at high BTD (1300 $\left.\mathrm{kg} \cdot \mathrm{m}^{-3}\right)$. For example, the values of MOR ranged from $9.9 \mathrm{MPa}$ for $P$. dactylifera at 1100 to $12.3 \mathrm{MPa}$ at 1300 $\mathrm{kg} . \mathrm{m}^{-3}$; however, the MOE values for this species ranged from $3146 \mathrm{MPa}$ at $1100 \mathrm{~kg} . \mathrm{m}^{-3}$ to $4142 \mathrm{MPa}$ at $1300 \mathrm{~kg} \cdot \mathrm{m}^{-3}$. It can be observed that all the mechanical properties of the panels manufactured from the two species at the three levels of BTD (9 combinations) were higher than the minimum standard requirements, as shown in Table 7 . These results are in agreement with the findings of Oyagade ${ }^{31}$; Cai et al. ${ }^{32}$; Ajayi and Olufemi $^{33}$. Ajayi and Badejo ${ }^{34}$ stated that it may be possible to produce stronger and heavier WCPs by increasing the board density.

The mechanical properties of the WCPs made in this study met the minimum requirements set by the International Organization for Standardization ${ }^{35}$ and compared favorably to the data published for different lignocellulosic materials under different manufacturing variables $^{10,12,36}$. Our results are in disagreement with those reported by Ajayi and Badejo ${ }^{34}$ in the case of the decrease in IB values observed with increasing target bard density, especially for the WCPs made from $P$. dactylifera. Those authors reported that the MOR was positively correlated with density (1000 to $1200 \mathrm{~kg} . \mathrm{m}^{-}$ ${ }^{3}$ ); however, the reverse trend was observed for IB. Our results indicated that both the MOR and the IB values increased with increasing target board density from 1100 to $1300 \mathrm{~kg} \cdot \mathrm{m}^{-3}$ (Fig. 4). The IB values exceeded by at least three-fold the requirement set forth by the ISO standard $(0.45 \mathrm{MPa})$. These results may be attributed to the use of pre-treated wood particles in manufacturing the WCPs, which resulted in improved compatibility between the wood particles and the cement. We found that all the mechanical properties of the WCPs were directly related to the board target density; Fig. 5 presents an example of the relationships between the MOR and the board target density $\left(\mathrm{R}^{2}=\right.$ 0.72 ). These results conform the fact that the density of wood-based panels exerts a significant influence on the mechanical properties of the panels and agree with those previously published on cement-bonded particleboard $^{34,37}$ and resin-particleboards ${ }^{32,38}$.

The dimensional stability characteristics of the panels produced from each species increased with increasing BTD of the panels from 1100 to $1300 \mathrm{~kg} . \mathrm{m}^{-3}$ (Table 7). The increased dimensional stabilities of the panels were evidenced by the decreases in all measured parameters, such as the water uptake (WU), thickness swelling (TS) and linear expansion (LE) after $24 \mathrm{~h}$ of water soaking. These results are in agreement with the results of studies carried out in other parts of the world $^{13,26}$. The lower the target panel density, the higher the voids that can be filled, leading to higher WU and TS (Almeida et al.) ${ }^{1}$. Generally, denser panels, which have fewer void spaces in the structure, are expected to absorb less water. Almeida et al. ${ }^{1}$ reported that WCPs made from babacu (Orbignya $s p$ ) at a density of 1200 $\mathrm{kg} . \mathrm{m}^{-3}$ had lower mechanical properties and lower dimensional stabilities (higher WU and TS) than did $1400 \mathrm{~kg} \cdot \mathrm{m}^{-3}$ density boards. They attributed these results to the higher volume of material consolidated into the higher density mat, which resulted in a higher board compaction ratio and, consequently, fewer void spaces inside the boards.

\section{Effects of species and wood to cement ratio on the properties of WCPs}

The wood to cement ratio (WCR) is one of the most important manufacturing process variables and tends to predominate in influencing the final density of the board, the physical and mechanical properties of the WCPs, and the dimensional stability characteristics of the WCPs. The analysis of variance indicated that the effect of the species, the wood/cement ratio, and the 
board density as well as the interaction between species and WCR were highly significant for all the mechanical properties and dimensional stability characteristics of the WCPs. However, this interaction was not significant for the physical properties of the WCPs, including the $\mathrm{MC}$ and density. The MCs of the WCPs ranged from $8.1 \%$ to $8.6 \%$ for $C$. erectus and from 8.5 to $8.9 \%$ for $P$. dactylifera, without any significant differences between the three levels of WCR. In the same manner, the densities of the WCPs ranged from 1237 to 1269 kg.m ${ }^{-}$ 3 . Thus, we described the interactions between the factors. Table 8 shows the mean values of the physical and mechanical properties of the WCPs manufactured from the two species at three levels of WCR as well as the dimensional stability characteristics of the panels.

Table 7. Properties of the WCPs of the four wood species at different target panel densities.

\begin{tabular}{|c|c|c|c|c|c|c|c|c|c|}
\hline \multirow[b]{2}{*}{$\begin{array}{c}\text { Wood } \\
\text { species } \\
\end{array}$} & \multirow{2}{*}{$\begin{array}{c}\text { Board } \\
\text { density } \\
\left(\mathrm{kg} / \mathrm{m}^{3}\right)\end{array}$} & \multicolumn{5}{|c|}{ Mechanical properties } & \multicolumn{3}{|c|}{ Dimensional stability } \\
\hline & & $\begin{array}{l}\text { MC } \\
(\%)\end{array}$ & $\begin{array}{l}\text { MOR } \\
\text { (MPa) }\end{array}$ & $\begin{array}{l}\text { MOE } \\
\text { (MPa) }\end{array}$ & $\begin{array}{c}\text { SHP } \\
(\mathbf{N})\end{array}$ & $\begin{array}{c}\text { JHN } \\
(\mathbf{N})\end{array}$ & $\begin{array}{c}\text { WU-24 } \\
(\%)\end{array}$ & $\begin{array}{c}\text { TS-24 } \\
(\%)\end{array}$ & $\begin{array}{c}\text { LE-24 } \\
(\%)\end{array}$ \\
\hline \multirow[t]{6}{*}{ P. dactylifera } & 1100 & 8.68 & 9.87 & 3146 & 1032 & 4679 & 24.70 & 1.54 & 0.60 \\
\hline & & $(0.8)$ & $(2.3)$ & $(419)$ & $(120)$ & $(535)$ & $(4.5)$ & $(0.7)$ & $(0.14)$ \\
\hline & 1200 & 8.41 & 11.46 & 3756 & 1294 & 6121 & 22.97 & 0.95 & 0.48 \\
\hline & & $(0.7)$ & $(2.0)$ & $(410)$ & (197) & $(771)$ & $(3.7)$ & $(0.5)$ & $(0.12)$ \\
\hline & 1300 & 8.87 & 12.28 & 4142 & 1376 & 6585 & 21.42 & 0.91 & 0.42 \\
\hline & & $(0.4)$ & $(1.9)$ & $(394)$ & (196) & $(940)$ & $(5.8)$ & $(0.4)$ & $(0.09)$ \\
\hline \multirow[t]{6}{*}{ C. erectus } & 1100 & 9.05 & 9.60 & 4562 & 1124 & 4708 & 21.06 & 0.68 & 0.38 \\
\hline & & $(0.4)$ & $(0.9)$ & $(362)$ & (267) & (667) & $(3.3)$ & $(0.1)$ & $(0.08)$ \\
\hline & 1200 & 7.52 & 11.71 & 5180 & 1655 & 5062 & 21.30 & 0.51 & 0.34 \\
\hline & & $(0.6)$ & (1.9) & $(548)$ & (219) & (947) & $(3.7)$ & $(0.2)$ & $(0.08)$ \\
\hline & 1300 & 8.79 & 13.95 & 5645 & 1651 & 6343 & 15.67 & 0.53 & 0.31 \\
\hline & & $(0.7)$ & $(2.2)$ & (616) & (163) & (991) & (4.4) & $(0.2)$ & $(0.07)$ \\
\hline $\mathbf{L S D}_{0.05}$ & & N. S. & 0.92 & 194 & 113 & 390 & 1.6 & 0.07 & 0.04 \\
\hline
\end{tabular}

Each value is an average of 9 specimens.

() The values between parentheses are standard deviations.

MC: moisture content, MOR: modulus of rupture, MOE: modulus of elasticity, IB: internal bond, SHP: screw holding power, JHN: Janka hardness number, WU: water uptake, TS: thickness swelling, LE: linear expansion.

$\mathrm{LSD}_{0.05}$ : for the interaction between the species and board target density.

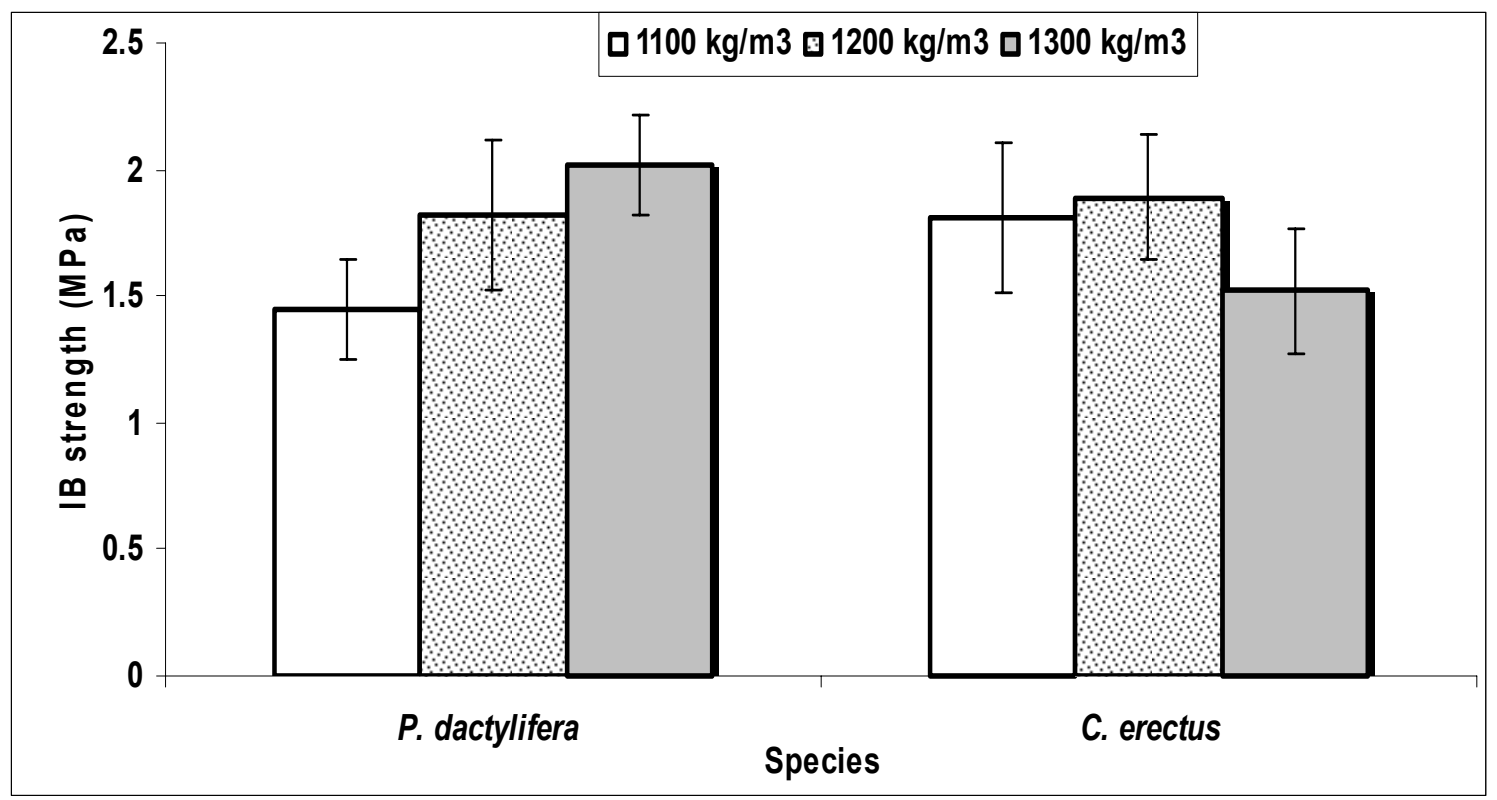

Fig. 4. Internal bond strength of the WCP from $C$. erectus and $P$. dactylifera at different levels of board target density 


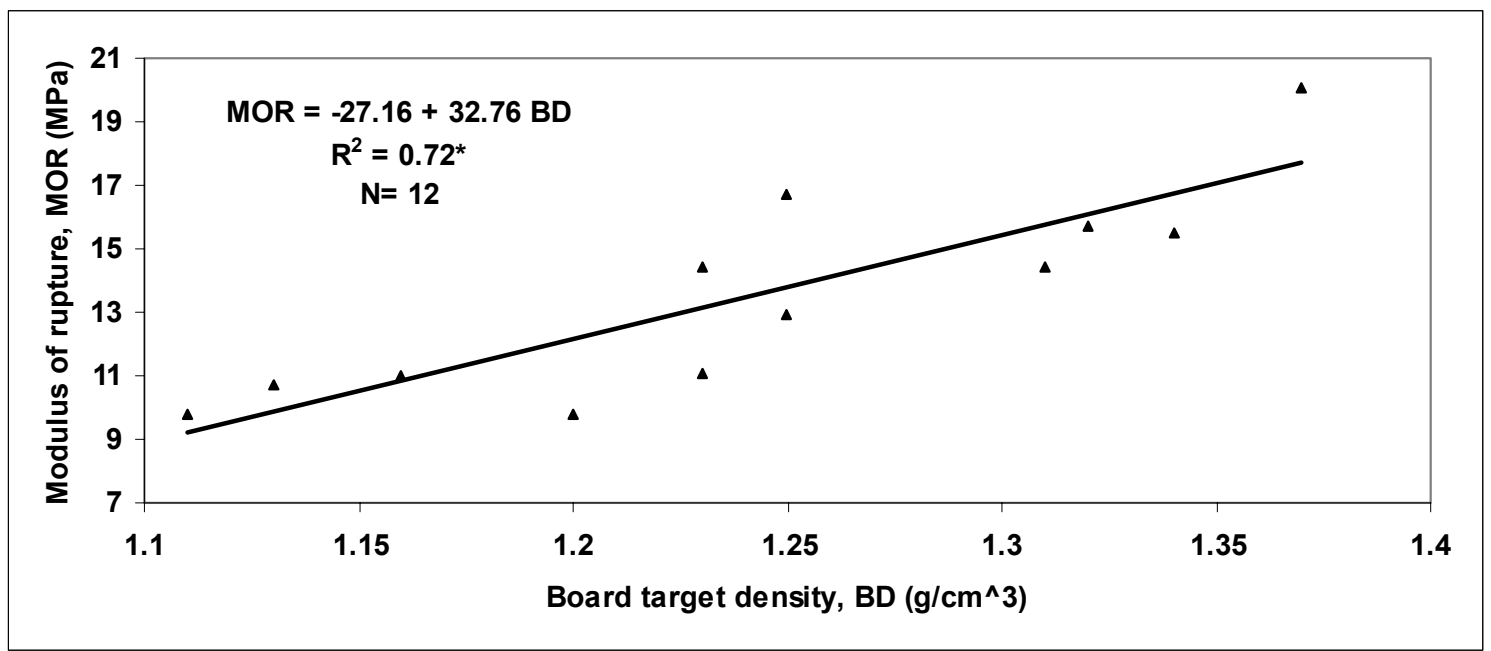

Fig. 5. Relationship between the modulus of rupture and the board target density of the CBP panels

Table 8. Properties of the WCPs of the four wood species for various target densities.

\begin{tabular}{|c|c|c|c|c|c|c|c|c|c|}
\hline \multirow[b]{2}{*}{ Wood species } & \multirow[b]{2}{*}{$\begin{array}{l}\mathbf{W} / \mathbf{C} \\
\text { ratio }\end{array}$} & \multicolumn{5}{|c|}{ Mechanical properties } & \multicolumn{3}{|c|}{ Dimensional stability } \\
\hline & & $\begin{array}{l}\text { MOR } \\
\text { (MPa) }\end{array}$ & $\begin{array}{c}\text { MOE } \\
(\mathbf{N})\end{array}$ & $\begin{array}{c}\text { IB } \\
(\mathrm{MPa})\end{array}$ & $\begin{array}{c}\text { SHP } \\
(\mathbf{N})\end{array}$ & $\begin{array}{c}\text { JHN } \\
(\mathbf{N})\end{array}$ & $\begin{array}{c}\text { WU-24 } \\
(\%)\end{array}$ & $\begin{array}{c}\text { TS-24 } \\
(\%)\end{array}$ & $\begin{array}{c}\text { LE-24 } \\
(\%)\end{array}$ \\
\hline \multirow[t]{6}{*}{ P. dactylifera } & $1 / 2$ & 13.39 & 3240 & 1.38 & 1065 & 4883 & 30.82 & 1.79 & 0.64 \\
\hline & & $(1.2)$ & $(472)$ & $(0.4)$ & $(131)$ & $(671)$ & $(2.2)$ & $(0.5)$ & $(0.12)$ \\
\hline & $1 / 3$ & 11.27 & 3639 & 1.77 & 1253 & 6020 & 21.64 & 0.99 & 0.48 \\
\hline & & $(1.2)$ & $(407)$ & $(0.3)$ & $(100)$ & $(757)$ & $(3.3)$ & $(0.3)$ & $(0.07)$ \\
\hline & $1 / 4$ & 8.94 & 4165 & 2.14 & 1383 & 6481 & 16.63 & 0.62 & 0.39 \\
\hline & & $(1.5)$ & $(442)$ & $(0.1)$ & (283) & $(812)$ & $(2.6)$ & $(0.2)$ & $(0.07)$ \\
\hline \multirow[t]{6}{*}{ C. erectus } & $1 / 2$ & 13.51 & 5601 & 1.06 & 1383 & 4217 & 19.01 & 0.74 & 0.42 \\
\hline & & $(2.7)$ & $(513)$ & $(0.4)$ & (146) & $(707)$ & $(3.3)$ & $(0.1)$ & $(0.06)$ \\
\hline & $1 / 3$ & 11.44 & 5185 & 2.04 & 1399 & 5156 & 20.28 & 0.56 & 0.33 \\
\hline & & (1.9) & (616) & $(0.6)$ & (419) & (840) & $(3.8)$ & $(0.1)$ & $(0.06)$ \\
\hline & $1 / 4$ & 10.31 & 4601 & 2.12 & 1647 & 6740 & 18.73 & 0.42 & 0.28 \\
\hline & & $(1.7)$ & (446) & $(0.4)$ & (332) & (903) & $(3.4)$ & $(0.2)$ & $(0.03)$ \\
\hline $\mathbf{L S D}_{0.05}$ & & 0.92 & 194 & 0.18 & 113 & 390 & 1.6 & 0.07 & 0.04 \\
\hline
\end{tabular}

Each value is the average of 9 specimens.

() Values between parentheses are standard deviations.

MC: moisture content, MOR: modulus of rupture, MOE: modulus of elasticity, IB: internal bond, SHP: screw holding power, JHN: Janka hardness number, WU: water uptake, TS: thickness swelling, LE: linear expansion.

$\mathrm{LSD}_{0.05}$ : for the interaction between the species and board target density.

According to the results tabulated in Table 8, two trends were observed for the effects of WCR on the properties of the WCPs. First, for each species, all mechanical properties, except the MOR, increased with increasing WCR from $1 / 2$ to $1 / 4$. Increasing the wood content in a mixture (that is, decreasing the WCR) increases the volume of wood particles and reduces the volume of the matrix, resulting in a lower bond strength $^{36}$. By contrast, increasing the wood content in a mixture increases the possibility of fiber-to-fiber bond formation, which results in a reduced interfacial contact area between the wood and the cement matrix.
Aggarwal et al. ${ }^{4}$ reported that the failure of WCPs is due to failures in fiber-to-fiber bonds or fiber-to-matrix bonds. At lower percentages of wood (higher levels of WCP), fiber-to-matrix bond failure predominantly occurs. Second, increasing the WCR significantly decreased the MOR of the WCPs. This result is in agreement with findings reported by Mohamed et al. ${ }^{13}$; Marzuki et al. $^{14}$; Ajayi and Olufemi ${ }^{33}$. They indicated that all MOR values are inversely related to the WCR. 



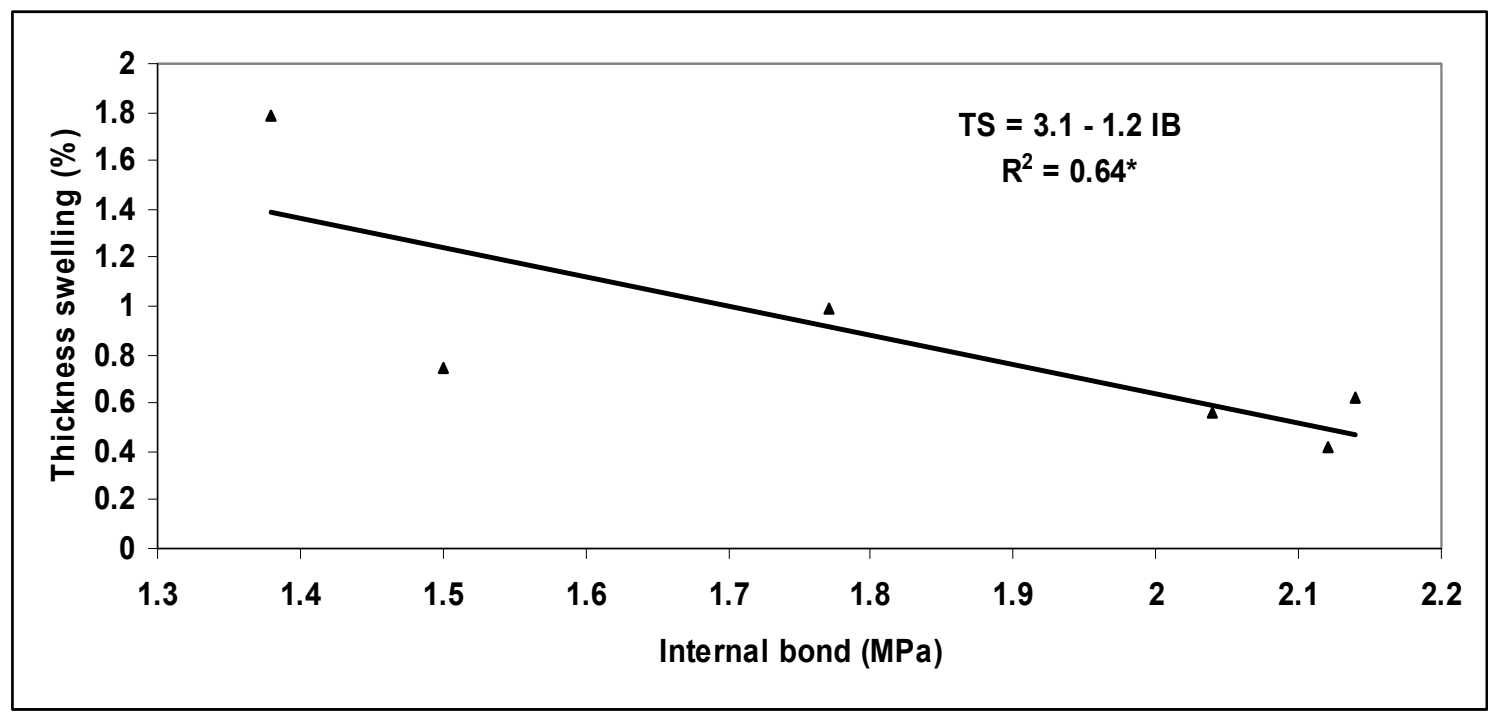

Fig. 6. Relationship between the internal bond (IB) and thickness swelling (TS) of the WCPs

This can be attributed to the higher content of wood particles in the WCPs, which resulted in enhanced flexural properties because the areas of stress concentration around the particles were more diffuse, resulting in increased applied stress ${ }^{33}$. Higher contents of cement may cause brittleness in the WCP and reduce the MOR.

According to the results in Table 8 for each species, changing the WCR from $1 / 2$ to $1 / 4$ significantly decreased the WU, TS and LE of the wood-cement panels after $24 \mathrm{~h}$ of water soaking. These results indicate that improvements in the dimensional stability of the produced WCPs were obtained by increasing the WCR. This could be because at low WCR, the wood particles are not encapsulated by the cement, which results in low bonding and therefore increased values of WU, TS and LE. These results are in agreement with the results of studies carried out in other parts of the world ${ }^{39,26,14}$. It concluded by Marzuki et al. ${ }^{14}$ that WCPs containing more cement exhibited lower TS values and were more stable in dimensions than those made from lower cement levels. They attributed this improvement to the fact that the wood particles were well bonded and protected by the cement matrix when the cement ratio was increased.

In fact, there is a direct correlation between TS and IB values for resin-bonded particleboards ${ }^{39}$. Panels with higher IB values can resist the stress due to wood expansion and press opening, resulting in lower TS. The results of the current work indicated that with increasing WCR from $1 / 2$ to $1 / 4$, the IB increased, while the TS decreased, as shown in Table 8 and Fig. 6. This result is in line with Menezzi et al. ${ }^{39}$, who found that higher IB values were associated with lower TS when exposed to water, which partially confirms the findings above.

These results demonstrated that WCPs could be manufactured from each of the two species in the current work using any wood to cement ratio. Improvements in the mechanical properties and dimensional stabilities of the produced panels were obtained by increasing the WCR. For industrial production, the selection of wood species, the level of board density and the WCR will be based on the end uses of the panels. Increasing the cement to wood ratio makes the WCPs difficult to handle, cut, nail and transport and results in inadequate MOR values ${ }^{40}$. These results confirmed that the effect of WCR was very important in determining the bending strength (MOR), and it can be considered the main factor controlling the properties of the WCPs.

\section{CONCLUSIONS}

From the above results, the following conclusions may be drawn:

1. Date palm midribs and the tree prunings of buttonwood are suitable raw materials for WCP production after particles pretreatment either with cold or hot water containing $3 \mathrm{wt} \%$ of chemical additives.

2. The properties of the WCPs made from the two species met the strength and dimensional stability requirements of the composite panels.

3. The results indicated that increasing the target density of the panels from 1100 to $1300 \mathrm{~kg} \cdot \mathrm{m}^{-3}$ had a positive effect on the properties of the panels produced. 
4. There was a positive correlation between the board density and all mechanical properties; and vice versa for the dimensional stability.

5. The wood/cement ratio significantly affected the properties of the WCPs made from the two species.

6. Changing the wood/cement ratio from $1 / 2$ to $1 / 4$ (by weight) resulted in an increase in all mechanical properties, with the exception of the MOR, and in the dimensional stabilities of the WCPs.

7. The increases in the dimensional stabilities of the panels were evidenced by decreases in all the measured parameters, such as the water uptake and thickness swelling after $24 \mathrm{~h}$ of water soaking.

\section{ACKNOWLEDGMENTS}

With sincere respect and gratitude, we would like to express deep thanks to National Plane for Science and Technology (NPST) program, King Saud University, Saudi Arabia for the financial support (project no 08ENV 517-02), sponsorship and encouragement.

\section{REFERENCES}

Almeida, R.R., C.H. del Menezzi and D.E. Teixeira. 2002. Utilization of the coconut shell of babacu (Orbignya sp.) to produce cement-bonded particleboard. Bioresource Technol. 85: 159-163.

Al-Mefarrej, H.A. 2009. Testing and enhancing the compatibility of five Saudi wood species for cementbonded particleboard industry. Alexandria Sci. Exchange J., Egypt 30 (3): 333-343.

Olorunnisola, A.O. 2007. Effects of particle geometry and chemical accelerator on strength properties of rattancement composites. African J. Sci. Technol. Sci. Eng. Series 8: 22-27.

Aggarwal, L.K., S.P. Agrawal, P.C. Thapliyal and S.R. Karade. 2008. Cement-bonded composite boards with arhar stalks. Cem. Conc. Comp. 30: 44-51.

Sukartana, P., R. Rushelia, I.M. Sulastinighsih. 2000. Resistance of Wood- and Bamboo-Cement Boards to Subterranean Termite Coptotermes gestroi Wasmann (Isoptera: Rhinotermitidae). In Proceedings of a Workshop on Wood Cement Composites in the Asia Pacific Region, Rydges Hotel, Canberra, Australia, 10 December; pp: 62-65.

Nasser, R.A. 2012. Physical and mechanical properties of three-layer particleboard manufactured from the tree pruning of seven wood species. World App. Sci. J. 19: 741-753.

Food and Agriculture Organization of the United Nations (FAO). 2011. State of Forestry, FAO, Rome, 199 pp.

Vaickelioniene, R., and G. Vaickelionis. 2006. Cement hydration in the presence of wood extractives and pozzolan mineral additives. Ceramics Silikaty 50 (2): 115122.
Wei, Y. M., and B. Tomita. 2001. Effects of five additive materials on mechanical and dimensional properties of wood cement-bonded boards. J. of Wood Sci. 47: 437444.

Semple, K.E., R.B. Cunningham and P.D. Evans. 2002. The suitability of five western Australian mallee eucalypt species for wood-cement composites. Ind. Crops Prod. 16: 89-100.

Pehanich, J.L., P.R. Blankenhorn and M.R. Silsbee. 2004. Wood fiber surface treatment level effects on selected mechanical properties of wood fiber-cement composites. Cem. Conc. Res. 34: 59-65.

Sudin, R. and W.A. Ibrahim. 2001. Cement bonded particleboard from Acacia mangium- A preliminary study. J. Trop. Forest Sci. 2: 267-273.

Mohamed, T.E., A.Y. Abdelgadir, M.M. Megahed and R.A. Nasser. 2011. Effect of mixing three lignocellulosic materials with different cement ratios on the properties of cement bonded particleboard. J. Sci. Tech. 12 (03): 44-54.

Marzuki, A.R., S. Rahim, M. Hamidah and R. Ruslan. 2011. Effects of wood:cement ratio on mechanical and physical properties of three-layered cement-bonded particleboards from Leucaena leucocephala. J. Trop. Forest Sci. 23 (1): 67-72.

Sotannde, O.A., A.O. Oluwadare, O. Ogedoh and P.F. Adeogun. 2012. Evaluation of cement-bonded particle board produced from Africana wood residues. J. Eng. Sci. Tech. 7 (6): 732-743.

Nasser, R. A. and H.A. Al-Mefarrej. 2011. Midribs of date palm as a raw material for wood-cement composite industry in Saudi Arabia. World Applied Sciences Journal 15 (12): 1651-1658.

Nasser, R.A., H.A. Al-Mefarrej and M.A. Abdel-Aal. 2011. Suitability of vine (Vitis vinifera L.) prunings for woodcement industry. American-Eurasian J. Agric. \& Environ. Sci. 11: 903-910.

Nasser, R.A. 1996. Compatibility of some wood species with portland cement and its enhancement using various treatments and chemical additives. M.Sc. thesis, Department of Forestry and Wood Technol., Faculty of Agric., Alex. Univ., Egypt, 118 pp.

Moslemi, A.A., J.F. Garacia, and A.D. Hofstrand. 1983. Effect of various treatments and additives on wood Portland cement-water systems. Wood Fiber Sci. 15, 165176.

ASTM. C150-84. 1984. Standard specification for Portland cement. Philadeliphia, Pa. U.S.A.

ASTM. 1989. Standard test methods for evaluating the properties of wood-base fiber and particle panel materials. ASTM D-1037, Philadelphia, Pa. U.S.A.

NREL Laboratory Analytical Procedure. 2005. Standard method for the determination ash in biomass. http://www.nrel.gov/biomass/analytical_procedures.html (January, 2014). 
Hachmi, M., A.A. Moslemi, and A.G. Camphell. 1990. A new technique to classify the compatibility of wood with cement. Wood Sci. Technol. 24: 345-354.

Simatupang, M.H. 1979. Der Wasserbedarf bei der Heretellung Zementgebundener Holzspanplatten. Holz. Roh. Werk. 37: 379-382.

Okino, E.Y., M.R. de Souza, M.A. Santana, M.V. da Alves, M.E. de Sousa and D.E. Teixeira. 2004. Cement-bonded wood particleboard with a mixture of eucalypt and rubberwood. Cem. Conc. Comp. 26: 729-734.

Papadopoulos, A.N. 2008. Natural durability and performance of hornbeam cement bonded particleboard. Maderas, Clencia Technol. 10: 93-98.

SAS. 2004. SAS guide to applications development, $2^{\text {nd }}$ edn.SAS Institute, Cary, North Carolina, USA.

Okino, E.Y.A., M.R. de Souza, M.A.E. Santana, M.V. Alves, M.E. de Sousa and D.E. Teixeira. 2005. Pysicomechanical properties and decay resistance of Cupressus spp. Cement-bonded particleboards. Cement and Concrete Composites 27: 333-338.

Fengal, D. and G. Wenger. 1989. Wood Chemistry, Ultra Structure reactions. Walter de Gruyter, N.Y.

Zheng, Y., Z. Pan, R. Zhang, B.M. Jenkins and S. Blank. 2006. Properties of medium-density particleboard from saline Athel wood. Ind. Crops Prod. 23: 318-326.

Oyagade, A.O. 1990. Effect of cement wood ratio on the relationship between cement-bonded particleboard density and bending properties. J. Trop. Forest Sci. 2 (2): 211-219.

Cai, Z., Q. Wu, J. Lee and S. Hiziroglu. 2004. Influence of board density, mat construction, and chip type on performance of particleboard made from eastern redcedar. Forest Prod. J. 54 (12): 226-232.

Ajayi, B. and B. Olufemi. 2011. Properties of cement-bonded flakeboard from Gmelina arborea and Leucoaena leucocephala. Int. J. Biol. Chem. Sci. 5 (2): 586-594.

Ajayi, B., and S.O.O. Badejo. 2005. Effects of board density on bending strength and internal bond of cement-bonded flakeboards. Journal of Tropical Forest Science 17 (2): 228-234.

ISO. 1987. International Standards for Cement-bonded particleboards- Board of Portland or equivalent cement reinforced with fibrous wood particles. International Standards Organization, ISO 8335, Switzerland.

Ashori, A., T. Tabarsa, K. Azizi, and R. Mirzabeygi. Woodwool cement board using mixture of eucalypt and poplar. Ind. Crops Prod. 34: 1146-1149.

Badejo, S.O. 1988. Effect of flake geometry on properties of cement-bonded particleboard. Wood Sci. Technol. 22: 357-370.

Hegazy, S.S. and I.M. Aref. 2010. Suitability of some fastgrowing trees and date palm fronds for particleboard production. Forest Prod. J. 60: 599-604.

Meneeis, C.H., V. Castro and M.R. Souza. 2007. Production and properties of a medium density wood-cement boards produced with oriented strands and silica fume. Maderas: Ciencia Technologia 9 (2): 105-116.

Zhou, Y., and D.P. Kamdem. 2002. Effect of cement/wood ratio on the properties of cement-bonded particleboard using CCA-treated wood removal from service. Forest Prod. J. 52 (2): 73-81. 


\title{
الملغص العرب
}

\section{تأثيركثلة لوح الغشب الأسمنت ونسبة الغشب إل الأسمنت علل خواص الواح النشب الحبيب

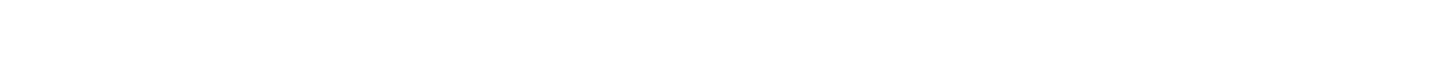

\author{
رمضان عبد للسيد ناصر
}

الخشبي ونسبة الخثب إلى الأسمفت أثرت بصورة معنوية

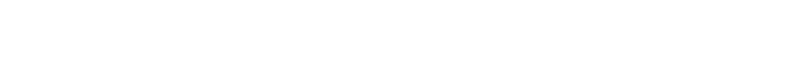

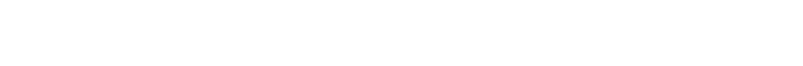

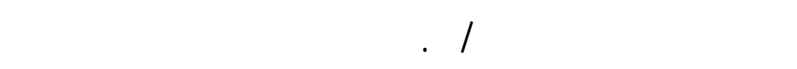

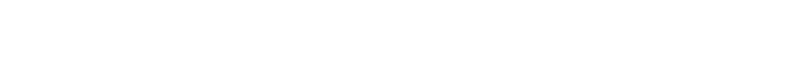
بكثافة اللوح النثب الأسمنتي. وبينت النتائج الهه بزياة النياة

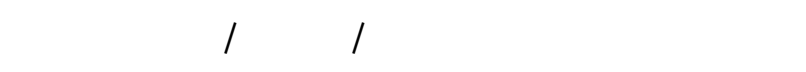

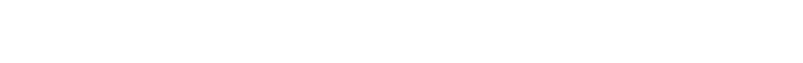
مما يبرهن على الن خواص الألواح الغشبية الأسمتتية تتهسن من خلال زيادة نسبة الغثب إلى الأسمتت مع التلكيد على النه في صناعة الألواح الغشبية الأسمنتية

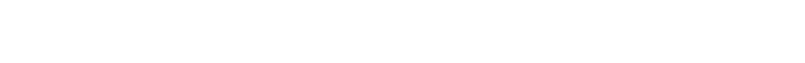
الإستخداملت التي يستخم فيها. الكاملت الفنتحية:

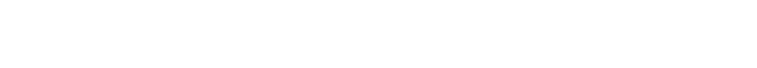

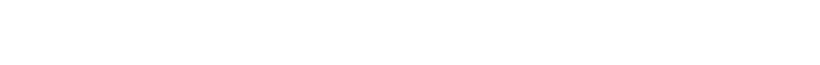
إلى الأسمتت، مواد لجنوسيليلوزية.
صنمن مشروع ممول من الظطة الوطنية للعلوم والقنية بجالمعة الملك سعود، لمستخمت العروق الونطي لجريد النخل (Phoenix dactylifera L) ونولنج نقليم أشجار

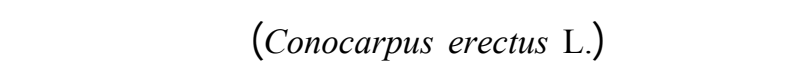

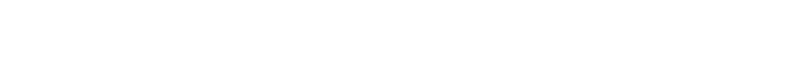
اللجنوسيليلوزية المتلحة في المملكة العربية المعتودية.

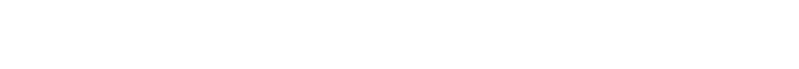

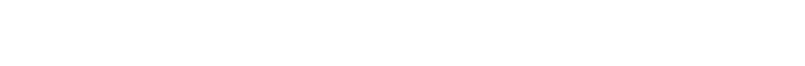

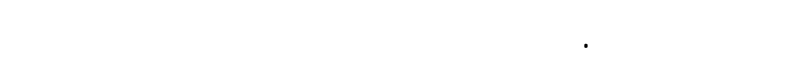
ظروف إنتاج محدة وهي ثلاث كثافلت للوح الثشبي المنتج

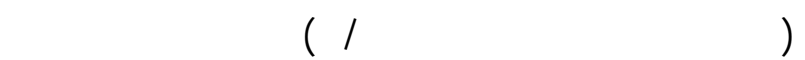

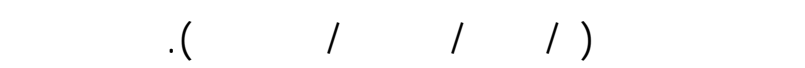

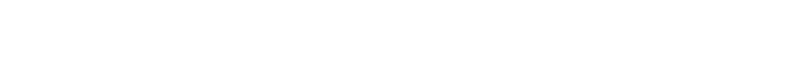

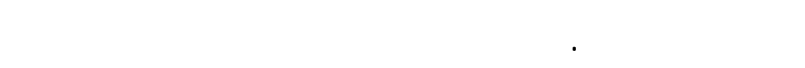

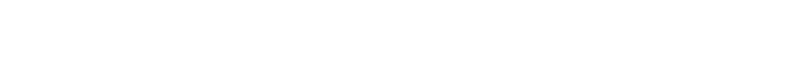

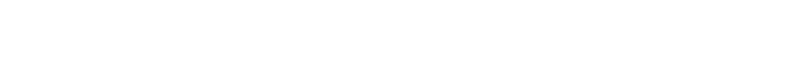

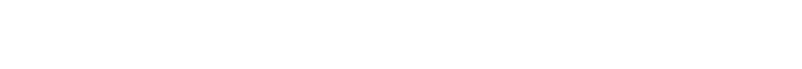
لتصلب الأسمت. كما أشارت النتائج إلى أن كثافة اللوح 